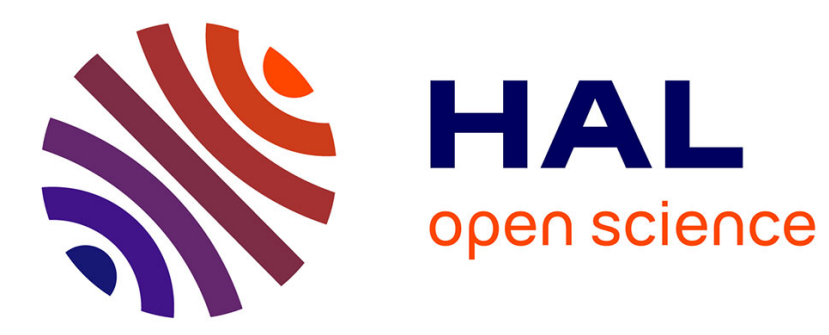

\title{
Forest management in Bolivia under Evo Morales: The challenges of post-neoliberalism
}

\author{
Pierre Gautreau, Laetitia Perrier Bruslé
}

\section{To cite this version:}

Pierre Gautreau, Laetitia Perrier Bruslé. Forest management in Bolivia under Evo Morales: The challenges of post-neoliberalism. Political Geography, 2019, 68, pp.110-121. 10.1016/j.polgeo.2018.12.003 . halshs-01954782

\section{HAL Id: halshs-01954782 \\ https://shs.hal.science/halshs-01954782}

Submitted on 13 Dec 2018

HAL is a multi-disciplinary open access archive for the deposit and dissemination of scientific research documents, whether they are published or not. The documents may come from teaching and research institutions in France or abroad, or from public or private research centers.
L'archive ouverte pluridisciplinaire HAL, est destinée au dépôt et à la diffusion de documents scientifiques de niveau recherche, publiés ou non, émanant des établissements d'enseignement et de recherche français ou étrangers, des laboratoires publics ou privés. 
Preprint of the paper:

Gautreau P. et Perrier Bruslé L. 2019. Forest management in Bolivia under Evo Morales: The challenges of post-neoliberalism. Political Geography, Volume 68 (110-121), January 2019. https://doi.org/10.1016/j.polgeo.2018.12.003

Forest management in Bolivia under Evo Morales: the challenges of postneoliberalism

PierreGautreau (Université Paris 1 Panthéon Sorbonne, UMR PRODIG, 2 rue Valette, 75005, Paris, France) \& Laetitia Perrier Bruslé (Université de Lorraine, Campus Lettres et Sciences Humaines, 23 boulevard Albert 1er, 54015, Nancy, France).

Abstract

Based on a study of the forest sector in the northern Amazon region of Bolivia, this paper addresses the reasons why the Bolivian so-called "postneoliberal" project is an adjustment of neoliberalism rather than a departure from it. First, Bolivia has aimed not so much at breaking away radically from neoliberal frameworks as at reasserting the importance of the state and of the national scale in regulatory actions. Second, the neoliberal period has left behind the insuperable legacy of a neoliberal approach to nature: by allowing local stakeholders to access forest resources, it has reinforced a commercial relationship with the non-human world. Third, it is not easy to reverse the internationalization of forest governance. All in all, the Bolivian state's reterritorialization of the country's margins through the control of forest resources has perpetuated processes that were initiated during the hybrid neoliberal period (1993-2005), though the focus has shifted from commoditizing the forest for the benefit of local stakeholders to facilitating the redistribution of this resource on a national scale. Since 2006 Evo Morales's forest governance has tried to integrate this multiscale dimension to create a pragmatic management model that combines agrarian colonization, conservation and extractivism. This explains both the apparent contradictions of the new Bolivian forest policy and the difficulties in creating a radically new form of governance. The case of Bolivian forests shows the extent to which neoliberalism has shaped spaces and scales in a way that guarantees its own resilience. 
In 2005 Evo Morales rose to power in Bolivia on a wave of protest against neoliberal policies, a movement that affected several South American countries in the course of those years. Morales promised the start of a new era. A decade later, even though some changes are indeed noticeable in redistribution patterns, there appears to be a marked difference between this discourse and an actual break from liberal models. Beyond the major changes that occurred during this period in fields of symbolic and political representation, we focus on the fact that the natural resource governance framework shows proportionally fewer relevant changes. Despite a global consensus amongst researchers about the durability of neoliberalism in Bolivia, few scholarly works have addressed the reasons for this permanence. Our aim is to contribute to the understanding of the limited changes brought about by the so-called "postneoliberal" South American wave by focusing on the Bolivian case.

Academic literature about Evo Morales's Bolivia, aside from literature by researchers who see this experience as the possible advent of a postliberal model (Escobar, 2010), emphasizes the "paradoxes" of Bolivian postneoliberalism (Freitas, Marston, \& Bakker, 2015). Several authors have commented on the durability of an economic model based on the extraction of natural resources (Bebbington \& Humphreys Bebbington, 2011; Gudynas, 2012; Kohl \& Farthing, 2012), while others have focused on the ongoing tension between the state and the indigenous movement (Zimmerer, 2015), or the inevitable transition from a revolutionary project to reformism (Webber, 2011). These diverse analyses concur on one point: through political pragmatism, the Bolivia of the early twenty-first century has developed its own brand of social liberalism (Andolina, Laurie, \& Radcliffe, 2009; Perreault \& Valdivia, 2010), and the economic and political frameworks inherited from the country's neoliberal foundations have overall been maintained. Counter-neoliberalisation processes, such as policies geared toward achieving cultural rehabilitation, social redistribution and resource nationalism have left dents in an overall market-oriented system.

The existence of a consensus on the fact that Bolivia has not broken away from liberalism does not, however, render the entire debate redundant. On the contrary, it prompts us to analyze the mechanisms through which the neoliberal model keeps evolving without ever genuinely changing and to understand the challenges that impede the advent of a radical counter-neoliberal model. In this paper we set out to address this question by observing changes in Bolivian forest governance from 2005 onward because changes in the status of nature are central to the neoliberal model and to its current mutations (Castree, 2008; Himley, 2008; Freitas et al., 2015), and because Bolivia's postneoliberal program has explicitly promoted a radical shift in its relationship with natural resources as being central to its model (Bridge, 2014). For example, Bolivia is well-known for its refusal to join the REDD+ system and for its skepticism, as of 2010, toward Payments for Ecosystem Services because this 
system reflected a commodification of nature which is regarded as both neoliberal and a breach of indigenous people's rights (Aguilar-Støen \& Hirsch, 2015) ${ }^{1}$.

Neoliberalism has not just brought nature onto the market-it has also deployed new governmentality to create wealth and to control populations through the attribution of rights to access resources. In order to understand the neoliberal mutation period introduced by Evo Morales, an analysis of the changes in these management techniques is essential. Forest governance in "Evo's Bolivia" (Farthing \& Kohl, 2014), this self-proclaimed postneoliberal state, is characterized by the gradual crumbling of the 1990s management model: the 1996 Forestry Law has increasingly been relaxed, land earmarked for logging is the subject of disputes, and forest conservation or sustainable management objectives are being explicitly challenged by the government. However, this subversion of neoliberal management does not in itself constitute a new governance model.

The ineffectuality of any actual institutional transformations raises two questions: what is distinctive about so-called postneoliberal resource governance? And why has a genuinely new model of management in the regulation of natural resources not emerged in Bolivia despite the changes brought about by Evo Morales's administration? This issue has recently been addressed regarding mining and hydrocarbon sectors. Andreucci \& Radhuber (2015) and Le Gouill (2016) mention the maintenance of former institutional arrangements for mineral exploitation, the continuity of lax environmental regulations and the state's active undermining of social movements against the expansion of mining as key explanations for the limits of what they call the "counter-neoliberal" reform. Kaup (2010) reports on the path dependence of the gas sector on the governance framework established during the 1980-90 decade, and the role of the conservative elite radically opposed to changes in this framework. For the forest sector, this question has never been clearly addressed despite extensive literature devoted to forest issues in Bolivia. Most of these publications deal with the problematic deployment of 1990 forestry reforms up to the present day (Cronkleton, 2014; Cronkleton, Pacheco, Ibargüen, \& Albornoz, 2009; Pacheco, Barry, Cronkleton, \& Larson, 2012; Pacheco, de Jong, \& Johnson, 2010a, 2010b; Pacheco \& Benatti, 2015; Pellegrini, 2011), with the measuring of the extent of deforestation (Müller, Pacheco, \& Montero, 2014; Müller, Pistorius, Rohde, Gerold, \& Pacheco, 2013) and with the weight of the different factors that determines it: property rights regime, political process of land distribution (Bottazzi \& Dao, 2013), accessibility and ethnicity (Boillat et al., 2015). Hirsch (2017) recently described the difficulties concerning the advent of a new forestry scheme but without dealing explicitly with its causes. We propose to take the analysis a few steps further by giving a precise description of the processes involved in the construction of this paradoxical,

\footnotetext{
${ }^{1}$ However, at COP 21 (2015) the Bolivian proposal reflected a softening of this hard line (Ministerio de Planificación del Desarrollo, 2015). By supporting a fairer redistribution of emission rights that takes into account the North's climate debt, Bolivia no longer rejects the idea of economic compensation for Ecosystem Services but instead discusses the implementation of these payments (Bétrisey \& Mager, 2016).
} 
not quite postneoliberal, model of governance. We will then provide some insight into the reasons why a clean break from the neoliberal forest governance model has not occurred.

In this paper we argue that the spatial dimension of the durability of neoliberalism has been underestimated and should be further underlined, particularly in the case of forests. Our thinking is rooted in two hypotheses. The first is that the changes in forest management under Morales's government have not consisted in inventing new regulations but in re-applying existing regulations on a new scale. In a political context where countrywide development through the agro-industry has become a priority, the forest has been given a new status: it has turned from a global heritage into stock for production. The state itself has gone from being a mediator between nature and society to being a development stakeholder. A second hypothesis would be that the current period is characterized by the "hybridization" of governance modes (De Castro, Hogenboom, \& Baud, 2015) with the institutional models inherited from the "revisionist" neoliberal period of 1995-2003 (Reed \& Bruyneel, 2010). The postneoliberal project has to take into account the fact that neoliberal governance has granted new rights over land and forest resources to indigenous and peasant communities who are now torn between their aspirations of autonomy and their wish to integrate the market. Power relationships between neoliberal stakeholders, who have been granted new territorial rights, and a state now founded on freedom, law, empowerment and market relations (Larner, 2003) are hard to reconcile with a project that re-establishes the state as the main actor of resource governance. The case of the forest offers different perspectives about the complex processes that explain the durability of the neoliberal framework: these are to be found not only in the "changing state-society relations" mentioned by Andreucci \& Radhuber (2015) for the mining sector but also in relationships with nature that have been shaped by the market on local and international scales.

Empirical documentation for this paper concerns the study of forest governance in the Amazon region located in the north of La Paz department known as "Norte La Paz". This district constitutes one of Bolivia's territorial margins. It is covered mostly by forest, with extensive cattle farming in the savanna and the growing presence of Andean peasant communities who practice family-based agriculture. It is a far cry from the hub of Bolivian agribusiness development in the Santa Cruz district. Extensive field surveys were carried out in this region from 2012 to $2015,{ }^{2}$ based on semi-structured interviews with forestry stakeholders operating on various scales. Locally, we met with most of the wood producers associations, wood transformation corporations, forestry officials and elected politicians in order to analyze the sector's economic and spatial organization, governance and conflicts. In addition, interviews were carried out with the national forest administration (Autoridad de Fiscalización y Control Social de Bosques y Tierra (ABT)) in the city of Santa Cruz and

\footnotetext{
${ }^{2}$ One of the authors carried out 92 interviews over seven field visits from 2012 to 2015 , and the other author 40 interviews over two field visits in 2014 and 2015.
} 
within the forestry department of the Ministry of the Environment (Ministerio de Medio Ambiente $y$ Agua) in the city of La Paz to identify the current national forest policy. Cartographic work combined geographical Open Data available in the Bolivian national Spatial Data Infrastructure "Geobolivia", with fieldwork data about the uses of the territory and the level of timber activity in each of the forest areas the state has attributed to the different stakeholders.

Our study focuses on three key dimensions of forest regulation in Bolivia. The first is the allocation to stakeholders of access rights to forest resources in order to address the dispossession of those with the least access to capital: indigenous groups and peasants. Positive redistribution policies were implemented in the 1990s to respond to the chaos caused by the first neoliberal phase and also after Evo Morales's election. By studying the changes in them we can assess whether they have contributed to ending dispossession or have only led to a reconfiguration of powers-for instance by granting farmers access to new forest rights to the detriment of indigenous people. The second aspect concerns the management techniques used for the implementation of forest governance. In keeping with existing studies on governmentality (Ong, 2007), we seek to understand how postneoliberal practices impact on relationships with nature; especially if post-2005 changes granted local stakeholders more autonomy from the market. And lastly, reconfigurations of scale are another aspect of forest regulations that needs to be studied. Neoliberalism thrived on promoting the local scale where Community-Based Natural Resource Management (CBNRM) is implemented with regard to transnational stakeholders, cooperation bodies and NGOs (Reed \& Bruyneel, 2010). The break in 2005 reestablished the state as one of the drivers of social change (Garcia Linera, Stefanoni, \& Svampa, 2007) but its effects on the reframing of scalar governance also needs to be acknowledged.

After analyzing academic debates on the rise of postneoliberalism in Latin America and defining it, we outline the conditions under which this model has developed in Bolivia. The second, third and fourth parts are dedicated to a case study on developments in forest governance in Norte La Paz, showing the tension between strong neoliberal legal frameworks and the challenging construction of a postneoliberal model from 2005 onward. In the last part we discuss the reason why a break has been impossible, which prompts us to propose a reinterpretation of the self-proclaimed "postneoliberal" process.

\section{IN SEARCH OF POSTNEOLIBERALISM, THE CHALLENGES OF A COUNTER MODEL}

In order to understand postneoliberalism, we first need to base our thinking on a clear definition of neoliberalism. Neoliberalism is three dimensional. Firstly, it is a doctrine that 
defends a utopian project of a society organized around self-regulating markets and free from political intervention (Cypher \& Dietz, 1997). Secondly, it is made up of a variety of current political practices that enhance conditions for capital accumulation even when they contradict the philosophical doctrine (Harvey, 2005; Peck \& Tickell, 2002)-the omnipotence of the market as a mediator of all kinds of relations is central to these neoliberal practices. Thirdly, neoliberalism is a manifestation of a specific social interest in restoring the power of an economic elite (Harvey, 2005). The second and third dimensions are interlinked. Because neoliberalism is ultimately a strategy to defend the social interest of the elite, it often adjusts to constraints even when these diverge from the neoliberal doctrine. In perpetual adaptation, neoliberalism is understood "as a specific form of capitalist development" (Watts, 2009, p. 63), rather than as an equivalent of capitalism. Addressing neoliberalism as a set of practices implies that it cannot exist in a pure form (Peck, Theodore, \& Brenner, 2012, p. 271). It always develops in an incomplete "hybrid" manner. In comparison, "postneoliberalism" is "a tendency to break with certain aspects of neoliberal policy prescriptions" (Ruckert, Macdonald, \& Proulx, 2016, p. 2). It particularly aims at reconstructing state power against free market regulation, at redirecting the market economy toward social concerns and at reviving citizenship via participation (Yates \& Bakker, 2014). Like neoliberalism, postneoliberalism combines two dimensions: a political philosophy of social justice and a set of political practices (ibid.). One important and much debated question is still pending: is postneoliberalism a radical break from the neoliberal model or is it "reconstituted neoliberalism" (Webber, 2011), or a "resurgent" (Peck et al., 2012) or "relegitimized" neoliberalism (Bond, 2009) accommodated for by the plasticity of neoliberalism itself? We propose to deal with this conundrum by taking into account the dual dimension of postneoliberalism. Postneoliberalism exists as a philosophical theory. As "an utopian ideology" (Wilson \& Bayón, 2017), it calls for a true break from neoliberalism. Escobar (2010) put forward the term "post-liberalism" to characterize this visionary plan. The question of how this ideological formation became rooted in material realities prompts us to qualify the postneoliberal record as a failure to escape the neoliberal paradigm (Grugel \& Riggirozzi, 2012; Gudynas, 2012; Kennemore \& Weeks, 2011; Macdonald \& Ruckert, 2009). By investigating "actually existing postneoliberalism" (Yates and Bakker 2014, p. 2), we observe how these postneoliberal practices reconstitute-or not-inequalities through a new arrangement of space and power (Elwood, Bond, Novo, \& Radcliffe, 2017; Kaup, 2014; Wilson \& Bayón, 2017) beyond the mere recognition of the fundamental resilience of neoliberalism.

The Latin-American Left came to power in the early 2000s on the of a powerful wave of popular protest against the neoliberal period. Ecuador, Bolivia, and Venezuela were at the forefront of the countermovement, while Argentina and Brazil opted for a less radical option. All in all, these new governments gave numerous signs of their intention to break away from 
the past and yet, a decade on, the foundations of the market economy, central to neoliberal policies, have not even started to shake, to say the least. At the very most, social factors have been reintegrated into the economy and new forms of citizen participation have been developed (Grugel \& Riggirozzi, 2012; Yates \& Bakker, 2014). The persistent commoditization of resources testifies to the resilience of neoliberalism. This can be interpreted as the result of global constraints imposed by the market's disciplinary nature (Gill, 1995). This has accompanied the emergence of neo-extractivist regimes based on the exploitation of raw materials in order to raise the resources needed to achieve social redistribution (Grugel \& Riggirozzi, 2012; Gudynas, 2012) in a context of resource nationalism (Veltmeyer, 2013) and in a developmentalist paradigm. According to this perspective, self-proclaimed "postneoliberal" governments have accepted the lack of alternatives to the existing neoliberal model and have only introduced adjustments to it in terms of social redistribution and the legal control of resources.

A decade after these self-proclaimed postneoliberal regimes came into being, the slight repercussions of adjustments to them have become visible and lead us to question the reality of a break, albeit a symbolic one. The extractivist model has barely changed the relationship with natural resources (Webber, 2009) and the influence of the indigenous culture's relational ontology has not become mainstream (Garcés, 2011). Even the political fight against inherited colonial inequalities has been weakened by the ambiguous effects of citizen participation: power relationships have been rearranged rather than suppressed. Postneoliberalism therefore poses significant challenges. It is difficult to perceive the true break from neoliberalism that it might promote in order to transform the country and yet its existence as a philosophical doctrine cannot be denied: it has been at the center of all political agendas for a decade.

A contextual outlook is needed to understand how postneoliberalism in its dual dimension exists in Bolivia. The country has been the scene of an ongoing process of neoliberalization. In 1985 Bolivia applied to the letter the principles of the Washington Consensus. Less than a decade later, faced with the serious social consequences of this conversion to a market economy, the country adopted a series of adjustments aimed at ensuring the viability of this transition to a market-centered society. Under the government of Gonzalo Sanchez de Lozada (1993-1997) compensation policies had been implemented through the introduction of multiculturalism, citizen participation, decentralization, access to natural resources and an area-based conservation policy (Bakker, 2005, 2010; Burdick et al., 2009; McCarthy, 2005; Postero, 2007). This new set of institutional practices was specific to Bolivia and somewhat innovative. They did not reduce this South-American state but transformed and relocated it. Bolivian decentralization, which was initiated by the 1994 Popular Participation Law (LPP), enabled the state to reach territories that had previously been excluded from its authority. By granting local municipalities a degree of financial and political autonomy, it opened the way for the advent of new citizenship and a political space for many indigenous and trade union 
leaders (Kohl, 2002; Lavaud, 2007). Neoliberal multiculturalism, acknowledged by the 1994 Constitution, brought about an in-depth transformation of relationships between the state and civil society on the basis of ethnic recognition. We often use the term "hybrid neoliberalism" to refer to this period of major change.

With the election of Evo Morales, Bolivia adopted a discourse about a coherent project to break away from neoliberalism. After being consolidated by the 2009 Constitution, the "process of change" claimed to promote equality by recognizing indigenous rights and by redistributing wealth in favor of the most disadvantaged. Economic and political equality were to converge with respect for the rights of nature in order to reach the ultimate aim of "living well", initially understood as being opposed to the commodification of nature (Laing, 2015). In the international arena, Bolivia's national identity was thoroughly transformed, and Evo Morales, as Bolivia's leader, attempted to cash in on this moral authority by developing a country that had thrown off the yoke of neoliberalism (Perrier-Bruslé, 2015). Thus, Evo Morales's process of change, often labeled a postneoliberal project, did in fact exist in terms of Bolivia's political agenda and project.

However, in practice, there was complete continuity with the neoliberal model. The government maintained an extractivist model of development justified by the need to increase state revenue for social redistribution and promoted by the rise in commodity prices during the first years of the 2000s. This process was labeled by researchers as "neo-extractivism" (Gudynas, 2010; Svampa \& Durand, 2011). The project to promote pro-indigenous and proenvironmental governance was undermined by tensions between indigenous rights (political equality) and economic rights (liberal redistributive justice), created by the return of a rentier state. In fact, by promoting natural resource extraction within a new state regulation framework, the state increased its social redistribution capacities for the whole population yet restricted the control exerted by local stakeholders over their respective territories and resources. How could indigenous autonomy be promoted while state power was being reaffirmed? The pro-environmental approach was also weakened by the ground effects of government-promoted extractivist expansion. The construction of an ideological framework based on living well had to be reframed to address the contradictions this engendered with the pursuit of former ways of managing natural resources, and to prevent it from fueling socioenvironmental conflicts (Andrade, 2016). More than a mere rhetorical ornament (Zimmerer, 2015), the living well motto became a model for dealing with tension between the country's all-necessary development and the protection of nature (Andrade, 2016; Laing, 2015). 


\section{2 - THE INSTITUTIONALIZATION OF FOREST GOVERNANCE IN NEOLIBERALISM HYBRIDIZATION (1993-2003)}

To understand current challenges in Bolivia's forest governance, we need to trace back over the history of the organization of the forest sector in the 1990s. Bolivia changed its forestry scheme in 1996 with the adoption of the Framework Law (Law 1700). Its main objective was to bring some order to the old "chaotic" system (Pacheco et al., 2010a), with the state allocating vast concessions at its discretion based on a volume of logged wood rather than on a surface area of land. The former system awarded concessions of less than five years and was dominated by large companies, leading to most of the population being deprived of forest resources while encouraging a lack of concern for long-term ecosystem management. The new forestry law aimed at promoting both sustainable forest management and greater access to these resources for the population, thus granting small-time players a formal status. Sustainable management objectives were pursued through the creation of twenty-year forest management plans, and through a requirement for the industry to use wood exclusively sourced through these channels.

In order to democratize access to forests, new rights were established, creating four land tenure schemes that lent importance to community rights (Table 1).

\begin{tabular}{|c|c|c|c|}
\hline Name & Beneficiaries & Tenure scheme & Status of land \\
\hline $\begin{array}{l}\text { Community } \\
\text { Forest } \\
\text { Organization } \\
\text { (OFC) }\end{array}$ & $\begin{array}{l}\text { Sub-group of an } \\
\text { indigenous } \\
\text { community }\end{array}$ & Usufruct & Collective ownership \\
\hline $\begin{array}{l}\text { Local Social } \\
\text { Association } \\
\text { (ASL) }\end{array}$ & $\begin{array}{l}\text { Group of residents } \\
\text { who have lived in } \\
\text { the region for at } \\
\text { least } 5 \text { years }\end{array}$ & $\begin{array}{l}\text { Usufruct under } \\
\text { concession scheme }\end{array}$ & $\begin{array}{l}\text { State-owned "fiscal" } \\
\text { land, representing } 20 \% \\
\text { of municipality forests } \\
\text { (municipal reserve). }\end{array}$ \\
\hline $\begin{array}{l}\text { Peasant } \\
\text { community }\end{array}$ & Peasant community & Usufruct & Collective ownership \\
\hline $\begin{array}{l}\text { Forest } \\
\text { concession }\end{array}$ & Private corporation & $\begin{array}{l}\text { Usufruct under } \\
\text { concession scheme }\end{array}$ & $\begin{array}{l}\text { State-owned, "fiscal" } \\
\text { land. Granted for a } 40- \\
\text { year period. }\end{array}$ \\
\hline
\end{tabular}

Table 1. Beneficiaries of forest rights established by the 1996 Law (modified from Cronkleton et al., 2009) 
The adoption of this new regulatory framework was complemented by a clarification of land tenure: it was necessary to identify state-owned land in order to distinguish between corporations' concessions and the "municipal reserve", that is the portion of the territory to be handed over to ASLs. In forest areas the Forestry Law was associated with the so-called "Ley INRA" (from the name of the Agrarian Reform Administration, Instituto Nacional de Reforma Agraria) that had been voted the same year: the former aimed to create a timber market, whereas the latter set out to establish a land market (Pacheco et al., 2010b). The simultaneous introduction of the two laws shows the coherence of this in-depth liberal reform of Bolivia's rural spaces. It is worth noting that the advent of the new forestry scheme did not involve massive land dispossession, as had been the case with previous mining cycles described by Fabricant \& Postero (2015): the granting of concessions to corporations was accompanied by a process of securing land tenure for indigenous and peasant communities.

Incidentally, the 1996 forestry reform created divisions within local society, which gave rise to social unrest during the period 2005-2015. Tensions arose between, on the one hand, OFCs and ASLs, which had received thousands of hectares of land that were to be split between a handful of people, and, on the other hand, peasant communities in which families were each awarded a small plot of land (50 hectares) of which only a small portion could be used for logging. A dispute broke out opposing forest rights based on collective ownership (OFC and peasant communities) and ASL concessions: in the latter, access to logging was not linked to a person's ethnicity or to the fact that they belonged to a farmers' trade union but to vague criteria regarding the time an individual had spent in the region.

The development of these new forestry standards and institutions emerged partly in response to demands from populations in wooded areas to be granted more equitable access to resources. It also served the interests of municipalities which, after the new 1994 Popular Participation Law, were required to raise their own resources via logging taxes (Pacheco, 2003). Moreover, a decisive role was played by international cooperation via the BOLFOR project which was funded and coordinated by the US agency USAID within its environmental program for Bolivia. Between 1994 and 2003 its members simultaneously developed the forestry law in collaboration with Parliament, drafted the relevant decrees and contributed to identifying state-owned forest areas (Nitler, 2001). The project also trained new organizations (OFCs and ASLs) in sustainable forest management techniques: forest inventories, management plans, logging and extraction methods. Only OFCs and ASLs benefitted from this support, unlike farming communities who were regarded as "enemies" of the forest by the BOLFOR team (Nitler, ibid.). US cooperation was strongly biased toward the new system in favor of players who were perceived to be best qualified to understand its foundations, to the detriment of peasants from the Andes now living in the country's forested lowlands. It also funded the creation of the land register in North and East Bolivia's forest areas (Lerch, 2014): the clarification of land tenure became a key element of the country's forestry strategy. 
We chose Norte La Paz as an interesting place for studying forest governance mutations from the 1990s onward. Located on the margin of Bolivia's most densely populated area, the region was gradually integrated into the rest of the country during the logging boom in the early 1990s. During that decade, neoliberal reforms brought about profound transformations in forest governance, as well as sociospatial reconfigurations caused by the establishment of indigenous territories, peasant communities and natural parks in a context of a growing wave of migration of Andean peasants in search of land. After the election of Evo Morales in 2005, Norte La Paz was one of the focal points for regulatory state extractivist policies: the state was planning an agro-industrial development model based on sugarcane production (Perrier Bruslé \& Gosalvez, 2014) using migrants' political support to consolidate its presence in the territory, which created tensions with regard to forest regulations. In Norte La Paz, the neoliberal forestry scheme first came into being in 1998-2003 and concerned the spatial organization of the most accessible forests (Figure 1) located within a 50-kilometer-wide strip north of the main road. The Andean piedmont starts southwest of this road: the steep gradient and classification of the area as a National Park makes logging impossible. Within less than ten years most accessible forest space had become occupied by corporation concessions (36\%) or ASLs (19\%), with indigenous OFCs and private ownership taking up 8 percent and 7 percent, respectively. Peasant communities settled in the spaces left vacant.

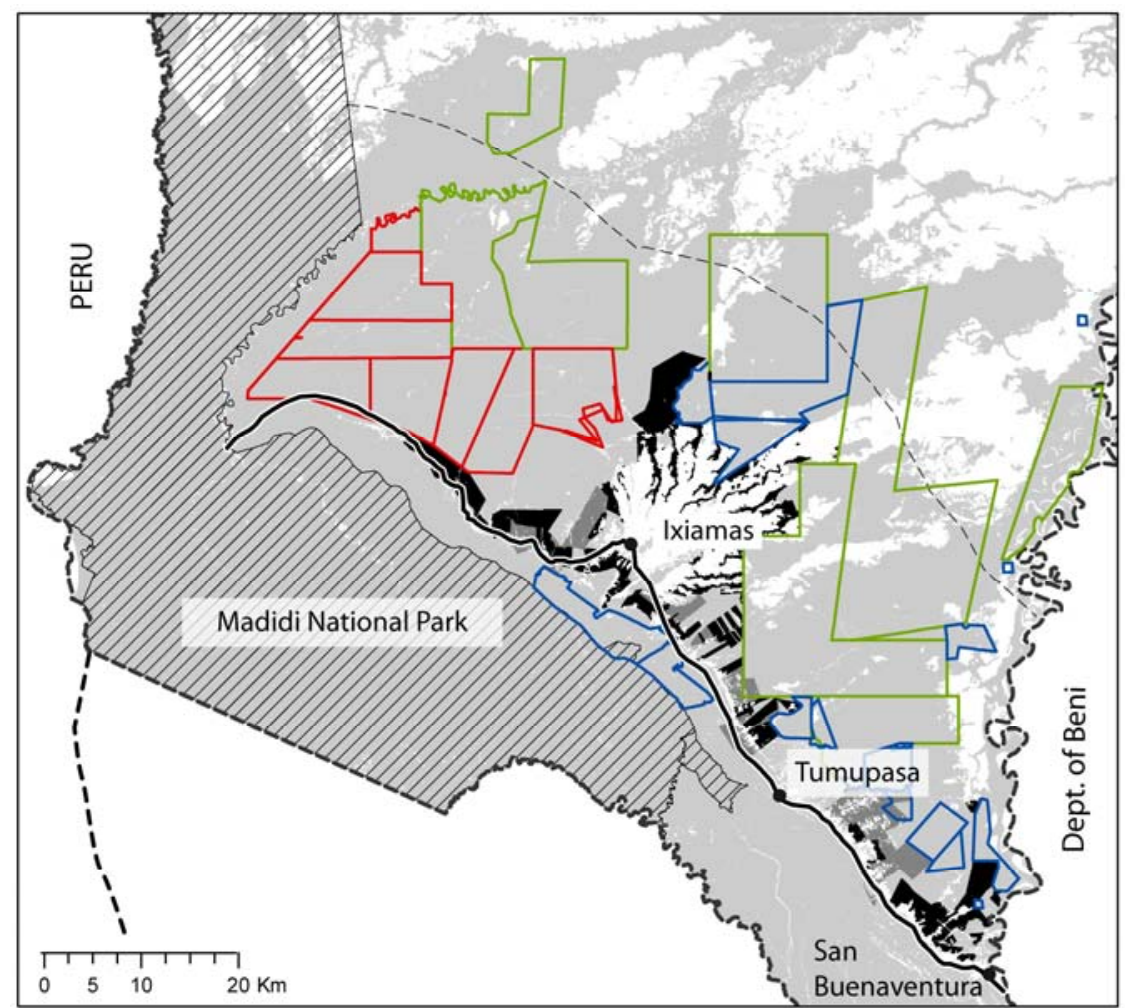

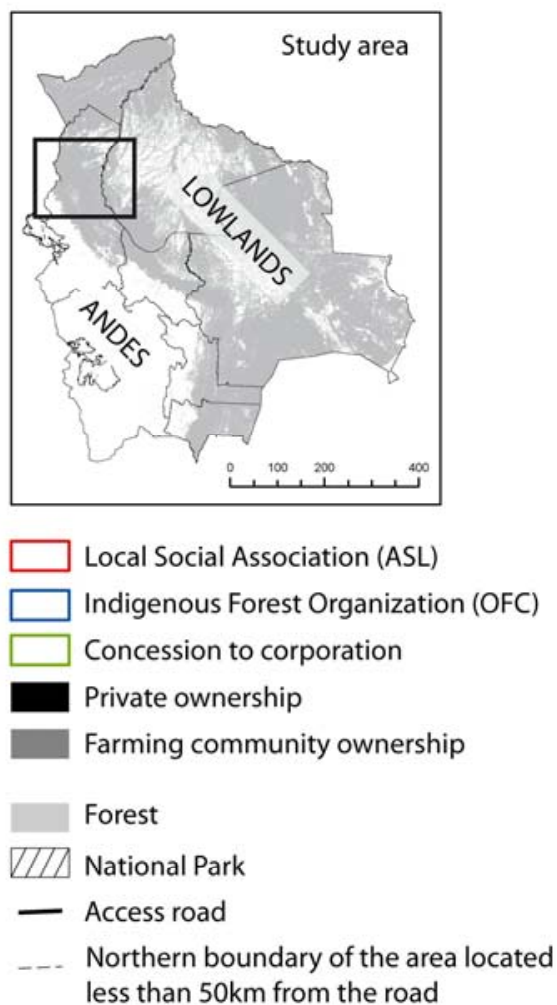

Figure 1. Allocation of forestry rights in Norte La Paz around 2005 
The definition of new forest rights benefitted from the converging agendas of various international stakeholders. Conservation NGOs, which initiated the creation of Madidi National Park in 1995 (see Figure 1), saw this new framework as a tool for safeguarding the park by reducing deforestation on its periphery. For the same reason, these organizations (The Nature Conservancy and Wildlife Conservation Society (WCS)) invested in capacity building for the management of municipalities or of indigenous territories. Various leaders or former leaders of Tacana indigenous territory (TCO Tacana) had underlined the importance of WCS for their political organization by creating an indigenous council (CIPTA, Indigenous Council of Tacana People) in $1987 .{ }^{3}$ USAID ultimately made the area one of its eight national pilot sites during the second phase of the BOLFOR project (2003-2006), while supporting several OFCs and ASLs with capacity building in forest management and commercialization.

In the course of its first decade, the introduction of the new forestry scheme therefore led to the creation of disparate types of forest tenure, both in terms of surface area and legal status. Although they received less land than corporation concessions and ASLs, peasant and indigenous communities benefitted from the rights their members had fiercely defended. The current ethnic dimension of forest tenure is inherited from this period. In addition, the creation of these tenures in close collaboration with international cooperation bodies established the region as a biodiversity reserve of global significance, as well as a pilot for models of local community-based resource management. This link between global and local scales is another aspect that has survived from this first neoliberal forestry scheme.

This period is representative of Bolivian hybridization of neoliberalism through which both state regulation capacities (through land tenure organization and the creation of the Superintendence for Forestry) and local forest governance were enhanced. The 1996 Law presented clear "not quite neoliberal" characteristics (Anthias \& Radcliffe, 2015), as it instigated collective forest rights (Table 1), unlike a number of liberal reforms in the 1990s that considered the existence of forest commons a threat to forest conservation (Pellegrini \& Dasgupta, 2011). The 1996 Forestry Law also gave the state the central role of allocating forest rights to social groups. Although the state's new role was reduced by the relative weakness of the administration (Pellegrini, 2011), the forestry reform is part of Bolivia's transformist brand of neoliberalism, whose ambition is to create a new state rather than to dismantle the existing one (Haarstad \& Anderson, 2009; Perreault, 2009; Postero, 2007). At the same time, by favoring private companies, the 1996 law remained faithful to the neoliberal ideal of liberalizing private businesses. The law did indeed grant a number of rights to communities and local groups (ASLs) - but without creating any intermediary bodies or infrastructures to provide forestry services or to ensure the distribution of timber-in order to

\footnotetext{
${ }^{3}$ Interview JGT, 04-29-2013 and AT, 04-30-2013.
} 
help these groups free themselves of corporations (Murphy \& Lawhon, 2011). In fact, the 1996 law provided for abundant and cheap raw materials for these companies, thereby enabling capital to penetrate forest peripheries that had previously been barely connected to national and global markets.

\section{2005-2016: FAILED ATTEMPTS AT REFORMING THE FORMER GOVERNANCE MODEL}

The forest governance mechanisms inherited from the late 1990s were challenged on Evo Morales's accession to power, with his administration proclaiming the need to reinvent a management model. However, there has been very little evidence of an endeavor to modify former forest governance. In fact, the state adopted a wait-and-see attitude: other than a few modifications made to the existing forestry scheme, the main standards were maintained. Indeed, the new forest policy is rather unclear and ambiguous due to the convergence of simultaneous needs to address demands from the agribusiness and from peasant sectors, of the dominant discourse that forests are a key means of reducing inequalities and poverty in rural areas, and of international pressure to prevent massive deforestation. There has been no new forestry law to replace the old one in spite of the publication of a new government forestry strategy in early 2008 (MDRAyMA, 2008). However, a series of presidential decrees was adopted in 2016 to develop three main lines of action: the strengthening of communitarian forestry through technical support and public procurement of communitarian forest production, the creation of a public investment fund for the whole sector, and the control of deforestation in order to carry through a reforestation program. These measures mainly came in response to pressure on the government from peasant and indigenous organizations, arguing for greater protection of local communities against the corporate sector (Hirsch, 2017). They nevertheless also reflected the government's ambition to develop a sector that provides a small contribution to the national GDP (3\% in 2016) and accounts for only a minor part of Bolivian exports (0.7\% in 2016 compared to 2.6\% in 2007) (Instituto Nacional de Estadísticas, 2017) owing to competition from Brazilian wood products. Besides their late issuance, these decrees are representative of some of the structural contradictions of current attempts to reform forest policy.

The clearly expressed intention to develop reforestation and to put a stop to deforestation is at variance with the main change in forest governance that has occurred over the recent period: the lifting of constraints on agricultural expansion in forest areas. In the lowlands, the government had to deal with two agricultural sectors-peasant and agribusiness-both of which demanded greater forest clearance. First, it had to respond to Andean peasants' claims to new land since this group provided the government with its main political support. They look at the forest from an agricultural perspective, that is mainly as land for assarting. Aside 
from the aforementioned decrees, other measures have brought more flexibility to restrictions on peasant agricultural activities in forests, which were almost totally banned in the past, and have linked forest management to agricultural development. "Integral management" has become the key notion at the heart of the new forest policy (MDRAyMA, 2008). The forest is seen as a provider of multiple goods and services, in addition to timber. State administration promoted the adoption of "Integral Management Plans", which were drawn up by communities through participatory processes, in which agriculture, agroforestry and woodland grazing were authorized for the first time alongside logging. These plans have made forestry controls in peasant communities less stringent and have legalized a range of formerly illegal activities.

Parallel to this, the government's decision to develop agricultural exports through the agribusiness sector (Castañon Ballivián, 2016), together with its political bargaining with the Santa Cruz elite (Urioste, 2014), led toward less restrictive policies to favour the expansion of commodity crops (mainly soybean). As a consequence, Law $337^{4}$ (2013) introduced a largescale plan to decriminalize illegal deforestation of landby farmers, while reducing the corresponding fines in exchange for the obligation to replant 10 percent of the surface area that has been deforested. For the agribusiness sector, which had been responsible for most of the massive deforestation of the Santa Cruz district during the 1990s and 2000s (Müller et al., 2014), this was a victory at a marginal cost. As for peasants, it is worth noting that they were barely affected by this law because the payment of fines only applies to farms of over 50 hectares: this leniency reflects the state's determination to avoid penalizing peasants for previous infringements concerning the forest. The government's pro-agriculture bias became clearer after the Tipnis conflict in 2011 which divided lowland indigenous organizations. This project to build a road right across a national park and indigenous land, which was presented by the government as a strategy to consolidate national territory, was strongly contested by its inhabitants who received support from the lowland indigenous federation (Perrier Bruslé, 2012). The conflict split this organization, CIDOB (Confederación de Pueblos Indigenas de Bolivia), into two political movements, one that supports the government and one that is politically opposed to Evo Morales (Hope, 2016). Under these circumstances the defense of indigenous territories and autonomy was sidelined in favor of both peasant and agribusiness strategies in the Oriente, while the election in August 2017 of a new CIDOB president, who supported the road construction, testifies to the grip the government has on this organization (Ortiz, 2018).

A second contradiction lies in the government's renewed commitment to strengthen (peasant and indigenous) community forestry management but without reviewing the main structural causes of its weakness that are linked mainly to tenure and organizational problems. For

\footnotetext{
4 "Law for the enforcement of food production and forest restoration".
} 
instance, the 2006 "Law for the Reconduction of Agrarian Reform" stated that no new forestry concessions would be created in the future and that only peasant communities would be granted access to state-owned land (Pacheco et al., 2010a), thus reducing the attribution of new rights to other stakeholders. Yet, aside from this measure, little was done to develop community forest management and in particular to consolidate the self-management capacity of indigenous communities and ASLs, who are dependent on external financial or operational support for planning their activities and for negotiating with corporations. As for peasant communities, they are still faced with the same structural constraints when setting up economically viable forest management mechanisms. Although they are collectively awarded land, peasant communities then divide it into lots of 50 hectares per family-which is too small an area to set up a common management plan covering hundreds of hectares (Cronkleton et al., 2009). This situation makes it impossible for a peasant-led community forestry sector to emerge.

The most salient reorientation of forest governance during the 2005-2016 period was motivated by the determination to rescale forest governance on a national scale. A new government agency, the Forest and Land Administration (ABT), was created in 2009 under the direct supervision of the Department for the Environment and Water. ABT, which had been independent, replaced the Superintendencia Forestal in accordance with the neoliberal principle that control should be taken away from the supposedly inefficient public administration. ABT was tasked with implementing a forest policy in keeping with the government's national policy. This administration asserted its authority in the 2010s by reassessing some corporation concession contracts and by canceling some of them. The restoration of central state took the form of attempts to sever direct links between the local forestry sector and global stakeholders, thus reestablishing the state's role as an intermediary or as the sole interlocutor. ABT is currently drawing up the statutes of a Bolivian forest certification mechanism (Certificación Forestal Boliviana) to allow forestry operators who want to access foreign markets to bypass international standards like the Forest Stewardship Council. More broadly speaking, the role of international cooperation in the forestry sector has been totally transformed. After tensions arose between USAID and Evo Morales's government, the BOLFOR (Bolivia Sustainable Forest Management Project) program was discontinued in 2006, putting an end to most major empowerment projects delivered for the benefit of OFCs and ASLs. International cooperation bodies and conservation NGOs, which once co-managed protected areas in collaboration with the upper echelons of the administration in charge of natural resource management, were evicted or subjected to increased controls. According to the government, this shift was aimed at reclaiming sovereignty over Bolivia's forests. During an informal conversation with Vice-President Alvaro García Linera, Evo Morales stated that "it is true that so-called forest reserves have 
been created from the North American empire and now it is as if they were untouchable and intangible" (Morales, 2015).

From 2006 onward the new government tightened controls on NGOs working on Bolivian territory, requesting that they submit triennial reports with a detailed breakdown of their sources of funding. Large NGOs working in nature conservation remained in Bolivia (The Nature Conservancy, Wildlife Conservation Society, Conservation Strategy Fund, Parks Watch-Bolivia, CARE, etc.) but took on a more technical role as the state reclaimed responsibility for designing and managing general policies. These changes were reflected in the launch in 2014 of a new cooperation program dedicated to forests, with funding from the Global Environmental Fund (a multilateral international fund that supports sustainable development projects). The program transformed the mechanisms of foreign aid by considerably reducing its autonomy: the sites and beneficiary groups are now mainly determined by Bolivian state departments; the project, designed in 2008, was launched after 2014 (Global Environment Fund, 2008).

In short, the period 2005-2016 saw minor changes in the forest governance inherited from the 1996 reform. The diverse actions undertaken by the government did not translate into a new forestry law but instead tended to contradict and to cancel each other out.

\section{LOCAL TENSIONS OVER FORESTRY IN NORTE LA PAZ}

Our local case study in Norte La Paz is emblematic of the national situation depicted above, showing that rising tensions affect the forestry scheme inherited from the 1990s, but without changing its main tenets. In Norte La Paz, local players complain of the system's inequity and its incapacity to create the conditions for a viable community-based forestry system-one of the main objectives of the 1996 Law. The main line of conflict opposes peasant communities with other groups such as corporations, OFCs and ASLs. Peasants denounce social and spatial inequalities in the allocation of forest rights: the attribution of vast areas to a small number of people through ASLs (on average 20,000 ha for 20 people), and the monopoly of the most accessible forests in the hands of OFCs, ASLs and corporations. This fuels resentment among the peasant population who habor a feeling of injustice. As a technical officer and former peasant union leader told us: "[the] native, the one who was born here, has the right to receive 500 hectares, but the one who comes from [outside] can't ask for more than 10 hectares [...]. In this place there can't be first-and second-class citizens, we all benefit from the same rights, but I would have liked to show you a chart published by INRA where you can see the number of native people and the amount of hectares they were given, [...] there is a huge difference..." (MH, Senior technical officer of the municipality of Ixiamas, 12-12-12). 
As in other parts of Bolivia, peasants protest that vast portions of state-owned land are still beyond their reach (Bottazzi \& Rist, 2012). They also argue that the current law makes it impossible for them to assart large areas for agricultural purposes. New peasant communities covet the concessions accorded to corporations (Figure 2) and have lobbied ABT into inspecting five of these concessions in the hope that the government might take the land back and allow their communities to settle there. This happened in 2007 with the PROINSA concession (77,000 ha), where the corporation was evicted (Ströher, 2013). Although it has so far proved unsuccessful, this strategy reflects peasant organizations' fierce opposition to the 1996 forestry scheme: by their actions they aim to counteract the 1990 s regulations against deforestation for agricultural purposes.

The attitude of peasant communities poses a threat to the future of ASLs, a key group of stakeholders created by the 1996 reform with little political leverage. Initially set up by relatively wealthy inhabitants of the town of Ixiamas who had settled on state-owned land in the Municipal Forest Reserve, ASL plots have the status of concessions rather than community-owned land (see Table 1). The land where they have settled is coveted by peasant communities with strong national and local political connections. In fact, the three groups of stakeholders have taken different paths to acquire power at national level. Indigenous people represented by CIDOB and peasant communities that have already settled and are represented by $\mathrm{FESPAI}^{5}$ have seen their power weakened within the central administration. By contrast, new communities fighting for land entitlement and which belong to the powerful national peasant union $\mathrm{CSTUCB}^{6}$ have gained a strong position via the departmental federation. As explained by one of the provincial leaders of this union "[our confederation] has a national scope, we are Evo Morales's avant-garde, and when there are problems in La Paz, the Tupaj Katari federation rises up, and no one can stop us" (NSP, leader 1 UNICA, 14/12/2012). In this tense context, members of ASLs live in fear of their rights being revoked by the State. This feeling of "legal insecurity" is rife in all ASLs in Bolivia (Castro Delgadillo, 2010). This situation is aggravated by the economic difficulties most of them face-long distances from the main saw mills, poor capitalization, difficulties in securing regular logging contracts-which goes to explain why their activities often come to a standstill (Figure 2).

The 1996 forestry scheme is also contested within indigenous communities. Inhabitants who did not join an OFC when they were set up (1997-2001) complain that they are now unable to access forest resources. In order to alleviate tensions, ABT is providing new indigenous groups with management plans for small plots $(<200 \mathrm{ha})$ located in the interstices between OFCs (Figure 2). The plans are valid for a period of twenty years: the plot can be logged for two years but has to be protected for the next eighteen years. However, this protection period

\footnotetext{
${ }^{5}$ Unionist Federation of Agricultural Producers of Abel Iturralde province.

${ }^{6}$ Unified Syndical Confederation of Rural Workers of Bolivia. Its local branch is called "Federación Departamental Única de Trabajadores Campesinos de La Paz 'Tupaj Katari'”.
} 
is unlikely to be enforced, considering the institutions' poor monitoring capacity. This situation contrasts with ABT's former practices, with management plans set out for plots of several thousand hectares, and it further reduces the chances of sustainable forest management.

As well as being the object of much criticism, the 1996 forestry scheme also suffers from faults in its design which have prevented it from meeting its two key objectives: the creation of a strong community forestry sector, and the implementation of sustainable management practices. This system has lost the backing of peasant communities, who should have been the main beneficiaries of the law. With poor access to capital, these communities cannot afford to undertake the preparatory work required before logging and therefore have to ask for cash advances from corporations, who have a monopoly over first-stage timber transformation (sawmills). Because the administration imposes a single mode of production based on largescale forest management plans, the communities are faced with high operating costs which they cannot cover with their own funds: they are forced to take out loans from the companies who buy their timber. This structural dependency on companies, together with all the red tape required to obtain an operating permit, has incited a number of communities to negotiate the sale of their produce below market prices. This situation is now commonplace across all of Bolivia's forests (Pacheco et al., 2010b). Prices have also been affected by the fact that the most sought-after wood varieties had been rendered almost extinct by the late 1990s due to logging: the forests of Norte La Paz now only provide relatively cheap varieties. In this context it has become less financially viable to apply sustainable forest management methods: communities now prefer to cash in on one-off illicit business opportunities than to follow a long-term vision (Cronkleton et al., 2009). Moreover, the sustainability of forests hinges on a long-lasting scheme to oppose a peasant mentality based on the exploitation of nature. A leader of a migrant-peasant community summed it up as follows: "The management plan is not as sustainable as they say because this little plot [that was cut] must be left alone for 20 years according to the law and then, as the money given by [the wood cut and sold from it] those 40 hectares are not enough to live on [...]. The forest management plan doesn't sustain us, it supports us for a year, and lets us die for 19 years" (DD, leader Porvenir community 1 , 09-09-2013). 


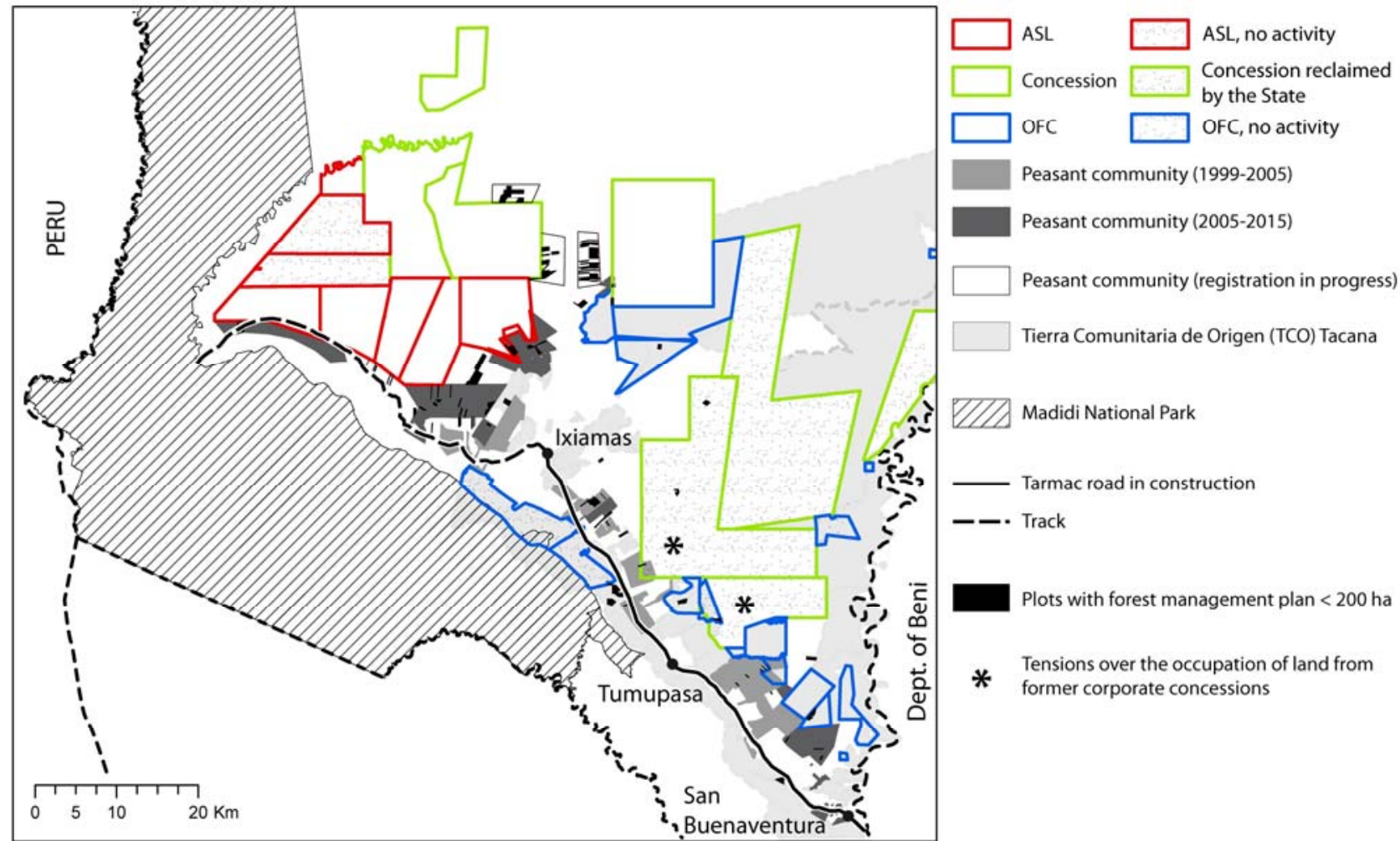

Figure 2. Tensions regarding forest rights in Norte La Paz around 2015

\section{DISCUSSION}

Twenty years after the adoption of the 1996 law, ten years after it was severely challenged by political leaders, and in spite of strong local tension over its application, this law still remains the reference framework for forest governance. How can this permanency be explained? In this section we discuss whether the factors influencing the durability of neoliberalism are the same for forests and other natural resources. In addition, we try to go further in explaining the durability of neoliberalism under postneoliberalism, by including spatially explicit factors, by incoporating long-term considerations about the geopolitics of Bolivia, and by underpinning long-established sociopolitical legacies of the 1990s. Various authors have tried to determine the reasons for the resilience of the neoliberal framework despite the launch of the process of change in 2005, by studying the mineral and hydrocarbon extraction sectors. Comparing their insights allows us to shed light on the special nature of the forest situation. On the one hand, forest and minerals/hydrocarbons show similar patterns regarding two particular points: first, path dependence on the economic structuring of the sector inherited from the 1990s (Kaup, 2010). Today the Bolivian forestry sector remains dominated by a few corporations that control the wood transformation stage and which are not favorable to the empowerment of community-based enterprises that might lead to new forms of wood extraction and commercialization. Second, the political weight of the social elite opposed to Morales's 
process of change proved to be the decisive factor (Kaup, 2012). Regarding forests, the need to negotiate with the conservative lowland elite dramatically reduced the pace of lowland colonization (perceived by this elite as a threat to its political predominance), and then the emergence of an important peasant agriculture in this part of the country. On the other hand, there are striking differences in patterns between the forest sector and the mineral/hydrocarbon sector. Whereas Andreucci \& Radhuber (2015) argue that the lax control of environmental laws contributes to maintaining the neoliberal framework for mineral extraction, in the Norte La Paz case the postneoliberal framework is paradoxically challenged by a relatively stringent environmental control inherited from the 1990s. For several reasons, these former environmental regulations have overall resisted attempts by the Morales government and its peasant union supporters to deconstruct them. Another difference lies in the nature and dynamics of social movements. As for mineral extraction, Andreucci \& Radhuber (2015) argue that the weakening of opponents to extractivism in the post-2005 period allowed neoliberalism to be maintained. Indeed, though extractivism is an ancient paradigm in Bolivia, it has been reactived in a new way in the neoliberal globalization framework (Siegel, 2017; Veltmeyer \& Petras, 2014). In the case of the forest, opposition to government attempts to facilitate forest clearance was not led by an institutionalized movement but by the groups that had been granted new rights according to the 1996 Law. There was an uneven weakening of these forces and while ASL groups suffered from peasant union critiques (without actually ceasing to exist however), indigenous groups remained fully mobilized. This comparison shows that an explanation of the durability of neoliberal management varies significantly depending on the kind of natural resource concerned and its location on the territory.

How the neoliberal forest governance framework has resisted in spite of the process of change has yet to be explored. A first set of explanations might be found in the long-standing characteristics of the Bolivian state and in the capacity of the Evo Morales's administration to incorporate late-twentieth-century neoliberal changes into its project to reconstruct national power and a legal framework. Post-2005 Bolivia did not fundamentally aim so much to break away totally from neoliberal frameworks as to reassess the importance of the national scale in regulatory action: this endeavor did not necessarily contradict the forest governance reform introduced by the 1996 Law, which laid the foundations of this national regulatory framework. Evo Morales's administration attempted to reinforce the role of the state as mediator between the market and civil society in order to protect the latter from the mechanisms of dispossession on a local and national scale. The definition of the process of change-described as postneoliberal—can be found in the objective the government set forth: "to consolidate [the forests' contribution] to the country's integral development" (Ministerio de Planificación del Desarrollo, 2015, p. 4). As with other natural resources, forestry is supposed to combat inequalities on a national scale, not just locally. This calls for forests to 
be made accessible to peasants from all over Bolivia, especially those who might have been excluded from the neoliberal distribution criteria in the 1990s that favored indigenous groups who were given vast areas of land. The government's discourse about this group is very critical. Indigenous people are either presented as victims of "colonial environmentalism" or suspected of collaborating with the "enemy" (NGO imperialists) (Garcia Linera, 2012). Some authors define postneoliberalism as a dual reorientation of the neoliberal model: the improvement of social redistribution and the development of democracy. However, few authors have highlighted the contradiction that is often to be found between these two processes: improving redistribution means consolidating the national scale (Bebbington \& Humphreys Bebbington, 2011), while developing democracy means reinforcing the local scale by strengthening the population's participation. Bolivian postneoliberalism, when analyzed through the lens of forest policies, is certainly closer to national than to local rescaling. This can be seen as evidence of resurging "resource nationalism" which is rooted in the history of Bolivian lost territories and which framed state transformation under the 1952 revolution (Kohl \& Farthing, 2012). However, these adjustments do not challenge the neoliberal framework: instead, they should be seen as a symptom of the neoliberal way of existing in a perpetual process of becoming.

Nevertheless, redistributive justice has struggled to materialize: on the ground, there has been minimal remodeling of forest rights in favor of peasants. The state has unofficially relaxed the standards of the 1996 Forestry Law in favor of agriculture but without introducing any real institutional innovations. For instance, Forest and Land Integral Management Plans were imposed on peasant communities without considering how they bore constraints that made them unsustainable (see part 4) and, as a result, the emergence of a peasant community forestry sector promised by the government never took place (Pellegrini \& Dasgupta, 2011). Furthermore, the state is aware that corporations are fundamental for the industrialization of the forest sector, which explains why it has maintained most of the concessions created during the late 1990s and 2000s.

In addition, it can be argued that the old forestry scheme provides a tool for territorial control that is in keeping with the new government's goal to structure and occupy the country's sparsely populated northern and eastern margins in accordance with the long-lasting Bolivian state objective to defend a national territory that has lost 54 percent of its total surface area since Independence (Groff Greever, 1987; Perrier Bruslé, 2007; Roca, 2001). The possibility of assigning tenure rights, granted by the 1996 Law, has been welcomed by Evo Morales's government as it reinforces its social and political capacity to control the margins of national territory.

A second set of explanations refers to three sociopolitical legacies of neoliberalism hybridization in Norte La Paz. The first is the definition of new social categories that 
originated from the Agrarian Reform and the 1996 Forestry Law. Rights to land and to logging are correlated with the social and ethnic categories to which an individual belongs. The law reinforced-and even created-these categories (Fontana, 2014). Power was redistributed between local stakeholders and, for instance in the case of the so-called indigenous people, their agency is conditioned by the local construction of their ethnicity (Anthias \& Radcliffe, 2015). Indigenous communities are extremely attached to the rights they obtained during this period and to the socioethnic categorization upon which these rights are based. Even peasant communities, while disputing indigenous people's rights over the forest, have also accepted the delimitation of their social category. The construction of these identities has not in fact fueled local conflicts but has led to more peaceful relationships. The president of CIPTA, for example, explained how a deal could be worked out with former peasants to obtain access to the land of a former corporation concession: "With [the peasant Union FESPAI] the discussion was quite hard, we struggled several times over the question of the land, the question of culture and so on [...], some of us almost died because of it, and it was hard to establish a pact of unity with our FESPAI brothers. But now we have decided to present our claims over land together" (NC, Leader of CIPTA, 10-09-2013). All in all, the stakeholder categories created in the neoliberal 1990s cannot be challenged by Evo Morales's new policies, despite their visible posture of change.

The second insuperable legacy of INRA and of forestry laws is the creation of a new relationship with nature. By enabling local stakeholders to access resources and to commercialize them under certain conditions, these laws have reinforced a commercial relationship with the non-human world. Far from being non-market spaces, indigenous and peasant lands are spaces "in which traditional livelihood activities coexist with various forms of market engagement" (Anthias \& Radcliffe, 2015, p. 267). Arguably, neoliberal laws have not been the only reason for this commoditization of nature-the integration of local stakeholders into the market is also part of this more global process-yet they have contributed to the phenomenon. The unique character of forest resources also needs to be taken into account: this sector has never been fully privatized and the rights to exploit it have always been granted by the state. The state has managed this resource by acting as an intermediary, whether by awarding concessions or by defining the conditions for its exploitation. As with hydrocarbons on the indigenous land of Chaco (Anthias \& Radcliffe, 2015), the land's natural resources were never quite owned by local populations, which has prevented the emergence of a truly autonomous indigenous territory. Although reinforced by rules that govern the allocation of this resource, ethnic differentiation has not given rise to original development patterns outside of capitalistic accumulation processes.

The third legacy of neoliberal frameworks is the internationalization of forest governance which has partly survived. The environmental value of forests was highlighted in the global arena in the 1990s thanks to the work of international conservation NGOs. It is now difficult 
for the government to challenge this status, in spite of measures that have made these areas more vulnerable-for instance, authorization of hydrocarbon exploration in these areas (Supreme Decree No. 2366, 2015). The country's dependency on conservationist frameworks which developed during the 1990s has paradoxically increased owing to the construction of the country's global environmental image after the election of Evo Morales and to the fact that, compared to minerals and hydrocarbons, the forest has been much more readily valued as a worldwide commons thanks to its biodiversity and carbon sequestration capacity. Presenting itself as a pioneer, if not a leader, with the ability to update the development paradigm into a less extractivist model (cf. the Introduction), Bolivia cannot afford to implement reforms that would drastically increase deforestation. And lastly, it is worth noting that the persistence of the neoliberal paradigm can be seen in patterns of international cooperation, since the transfer of forest management from NGOs and foreign aid agencies to the state is still largely incomplete. The state still depends on these organizations to provide the salaries of civil servants working on the ground, to develop national forest certification schemes and to introduce new integral management plans-a set of measures in Norte La Paz that are currently jointly funded by the Global Environmental Fund, the Japanese cooperation agency JICA and the Danish cooperation agency DANIDA, respectively. However, unlike in the past, the global scale of forest governance does not manifest itself through concrete links between local and global stakeholders (indigenous people/NGOs) but indirectly through the state. Once again, it appears that the path Bolivia has followed since 2005 has been mostly a neoliberal variant characterized by the restoration of the state and the national scale.

\section{CONCLUSION}

Bolivian self-proclaimed "postneoliberalism" stands out for its ability to cope with polysemy. Though we cannot deny that some innovativeness has been introduced during Evo Morales's era, it should be regarded as another mutation of neoliberalism, proof of its resilience to the internal tensions it generates. It demonstrates the variegation of neoliberalism (Brenner, Peck, $\&$ Theodore, 2010), which was never anything but a "a contested set of processes, comprised of diverse policies, practices, and discourses" (Perreault, 2009, p. 137). This diversity can be explained by the fact that the neoliberalization of spaces, people and the environment can be based on different goals. This study shows that a complex group of factors converge toward the persistence of neoliberalism as a plastic and evolutive frame. This persistence contrasts with the fervent call to overcome it through the "process of change" and evolution. Path dependence on previous economic structures and the influence of the conservative elite have not been brought under control, as can be seen in the hydrocarbon and mineral sectors. And more specifically, no significant progress has been made to free community-based forest management experiments from their reliance on the corporate sector for transforming the 
wood they produce. The major sociocultural changes triggered by the neoliberal period explain the limits of counter-neoliberalization in forestry, unlike in the hydrocarbon sector where stakeholders obtained no new rights during the neoliberal era. The relationship with nature mediated by the market seems to be irreversible in the short and medium term because all neoliberal actors would fight for its permanence.

A major contribution of this study is the way it reassesses the importance of spatial and scalar factors to help understand the durability of neoliberalism in the Bolivian context. Lowland indigenous groups, who were threatened by the advance of the agricultural frontier from the 1980s onward, were deeply affected by the attribution of land rights during the hybridization of neoliberalism in the 1990s. Today, they are still resisting Evo Morales's "process of change", which paradoxically threatens the spatial rights they acquired in the past. Another point concerns the surprising coherence between the state's various historic goals to secure its territorial margins, which have been strengthened by the tighter controls over forests imposed by the 1996 neoliberal law. This law has provided a tool that Evo Morales's government is not likely to abandon in a hurry because its eastern, depopulated frontiers are mainly forest spaces. And lastly, the globalization of forest governance limits the capacity of the Bolivian state to undermine the governance framework of the 1990s. In comparison with non-living resources, forests and particularly tropical ones, are seen as a worldwide commons thanks to their biodiversity and carbon sequestration capacity, which hinder attempts to convert them to agriculture.

In fact, the postneoliberal process of change is characterized by one main innovative process: the rescaling on a national scale of forest governance, which previously bypassed this level, and the direct linking of local and global scales following the focus of the neoliberal paradigm on local/global alliances. Yet even this original postneoliberal feature needs to be qualified: though the new government has attempted a better redistribution of forest revenues on a national scale, it has largely failed in this endeavor, while only partially affecting local arrangements inherited from the neoliberal period. The fact is that "postneoliberal" forest governance has not erased the different scales but has made them more complex: it has sought to reinforce and to add the national scale (as a reserve of land for development) to the global scale (the Bolivian forest as part of the world's natural heritage) and the local scale ( tosupplement agricultural income). Thus "postneoliberal" forest governance has tried to integrate this multiscale dimension to create a pragmatic management model that combines agrarian colonization, conservation and extractivism. This explains both the apparent contradictions of the new Bolivian forest policy and the difficulties in creating a radically new form of governance. The case of Bolivian forests shows how profoundly neoliberalism has shaped spaces and scales in a way that guarantees its high resilience. 


\section{FUNDING}

This work received support from the French Agence Nationale de la Recherche (ANR) under the Périmarge project (2012-2016).

\section{REFERENCES}

Aguilar-Støen, M., \& Hirsch, C. (2015). REDD and Forest Governance in Latin America: The Role of SciencePolicy Networks. In B. Bull \& M. Aguilar-Støen (Eds.), Environmental Politics in Latin America: Elite Dynamics, the Left Tide and Sustainable Development (pp. 171-189). London: Routledge.

Andolina, R., Laurie, N., \& Radcliffe, S. A. (2009). Indigenous Development in the Andes: Culture, Power, and Transnationalism. Durham: Duke University Press.

Andrade, P. R. (2016). The Government of Nature: Post-Neoliberal Environmental Governance in Bolivia and Ecuador. In F. Castro, B. Hogenboom, \& M. Baud (Eds.), Environmental Governance in Latin America (pp. 113-136). Palgrave MacMillan.

Andreucci, D., \& Radhuber, I. M. (2015). Limits to "counter-neoliberal" reform: Mining expansion and the marginalisation of post-extractivist forces in Evo Morales's Bolivia. Geoforum. https://doi.org/10.1016/j.geoforum.2015.09.002

Anthias, P., \& Radcliffe, S. A. (2015). The ethno-environmental fix and its limits: Indigenous land titling and the production of not-quite-neoliberal natures in Bolivia. Geoforum, 64, 257-269. https://doi.org/10.1016/j.geoforum.2013.06.007

Bakker, K. (2005). Neoliberalizing Nature? Market Environmentalism in Water Supply in England and Wales. Annals of the Association of American Geographers, 95(3), 542-565. https://doi.org/10.1111/j.14678306.2005.00474.x

Bakker, K. (2010). The limits of 'neoliberal natures': Debating green neoliberalism. Progress in Human Geography, 34(6), 715-735. https://doi.org/10.1177/0309132510376849

Bebbington, A., \& Humphreys Bebbington, D. (2011). An Andean Avatar: Post-Neoliberal and Neoliberal Strategies for Securing the Unobtainable. New Political Economy, 16(1), 131-145. https://doi.org/10.1080/13563461003789803

Bétrisey, F., \& Mager, C. (2016). La contribution bolivienne à la COP 21 au prisme de la justice environnementale. EchoGéo. https://doi.org/10.4000/echogeo.14442

Boillat, S., Dao, H., Bottazzi, P., Sandoval, Y., Luna, A., Thongmanivong, S., ... Giraut, F. (2015). Integrating Forest Cover Change with Census Data: Drivers and Contexts from Bolivia and the Lao PDR. Land, 4(1), 45-82. https://doi.org/10.3390/land4010045

Bond, P. (2009). Realistic Postneoliberalism—a view from South Africa. Development Dialogue, (51), 193-212.

Bottazzi, P., \& Dao, H. (2013). On the road through the Bolivian Amazon: A multi-level land governance analysis of deforestation. Land Use Policy, 30(1), 137-146.

https://doi.org/10.1016/j.landusepol.2012.03.010 
Bottazzi, P., \& Rist, S. (2012). Changing land rights means changing society: the sociopolitical effects of agrarian reforms under the government of Evo Morales. Journal of Agrarian Change, 12(4), 528-551.

Brenner, N., Peck, J., \& Theodore, N. (2010). Variegated neoliberalization: geographies, modalities, pathways. Global Networks, 10(2), 182-222. https://doi.org/10.1111/j.1471-0374.2009.00277.x

Bridge, G. (2014). Resource geographies II The resource-state nexus. Progress in Human Geography, 38(1), 118-130. https://doi.org/10.1177/0309132513493379

Burdick, J., Oxhorn, P., \& Roberts, K. M. (2009). Beyond neoliberalism in Latin America? societies and politics at the crossroads. New York: Palgrave Macmillan. Retrieved from http://public.eblib.com/choice/publicfullrecord.aspx?p=474846

Castañon Ballivián, E. (2016). Discurso empresarial versus realidade camponesa na produção de soja no departamento de Santa Cruz, Bolívia. In E. A. Bülher, M. Guibert, \& V. L. De Oliveira (Eds.), Agriculturas empresariais e espaços rurais na globalização (pp. 255-274). Porto Alegre: UFRGS.

Castree, N. (2008). Neoliberalising nature: processes, effects, and evaluations. Environment and Planning A, 40(1), 153 - 173. https://doi.org/10.1068/a39100

Castro Delgadillo, M. (2010). Análisis situacional rápido del sector forestal boliviano (p. 58). La Paz, Bolivia: Global Consultores en Desarrollo Sostenible.

Cronkleton, P. (2014). Examining the Role of Property Rights and Forest Policy in Forest Governance: Lessons from Mexico, Bolivia, and Cameroon. In B. Greenville \& B. Child (Eds.), Adaptive Cross-scalar Governance of Natural Resources (pp. 35-53). New York: Routledge.

Cronkleton, P., Pacheco, P., Ibargüen, R., \& Albornoz, M. A. (2009). Reformas en la tenencia forestal en Bolivia: La gestión comunal en las tierras bajas. La Paz, Boliva: CIFOR / CEDLA.

Cypher, J., \& Dietz, J. (1997). The process of economic development. London: Routledge.

De Castro, F., Hogenboom, B., \& Baud, M. (2015). Gobernanza ambiental en América Latina. Buenos Aires: CLACSO, ENGOV.

Elwood, S., Bond, P., Novo, C. M., \& Radcliffe, S. (2017). Learning from postneoliberalisms. Progress in Human Geography, 41(5), 676-695. https://doi.org/10.1177/0309132516648539

Escobar, A. (2010). Latin America at a crossroads : alternative mordernisations, post-liberalism or postdevelopment? Cultural Studies, 24(1), 1-65.

Fabricant, N., \& Postero, N. (2015). Sacrificing Indigenous Bodies and Lands: The Political-Economic History of Lowland Bolivia in Light of the Recent TIPNIS Debate: Sacrificing Indigenous Bodies and Lands. The Journal of Latin American and Caribbean Anthropology, 20(3), 452-474. https://doi.org/10.1111/jlca.12173

Farthing, L. C., \& Kohl, B. (2014). Evo's Bolivia: continuity and change. Austin: University of Texas Press.

Fontana, L. (2014). Indigenous peoples vs peasant unions: land conflicts and rural movements in plurinational Bolivia. Journal of Peasant Studies, 41(3), 297-319. https://doi.org/10.1080/03066150.2014.906404

Freitas, C., Marston, A. J., \& Bakker, K. (2015). Not-quite-neoliberal natures in Latin America: An introduction. Geoforum, 64, 239-245. https://doi.org/10.1016/j.geoforum.2015.05.021 
Garcés, F. (2011). The Domestication of Indigenous Autonomy in Bolivia. From the Pact of Unity to the New Constitution. In B. Gustafson \& N. Fabricant (Eds.), Remapping Bolivia, Resources, Territory, and Indigeneity in a Plurinational State (pp. 46-67). Santa Fe: School for Advanced Research.

Garcia Linera, A. (2012). Geopolítica de la Amazonía Poder hacendal-patrimonial y acumulación capitalista. La Paz: Vicepresidencia del Estado Plurinacional de Bolivia. Retrieved from http://comunicacion.presidencia.gob.bo/docprensa/pdf/20120911-10-54-37.pdf

Garcia Linera, A., Stefanoni, P., \& Svampa, M. (2007). Entrevista a Álvaro García Linera: 'Evo simboliza el quiebre de un imaginario restringido a la subalternidad de los indígenas. OSAL, 8(22), 144-164.

Gill, S. (1995). Globalisation, Market Civilisation, and Disciplinary Neoliberalism. Millennium - Journal of International Studies, 24(3), 399-423. https://doi.org/10.1177/03058298950240030801

Global Environment Fund. (2008). Conservación de la biodiversidad a través de la gestión sostenible de los bosques por los actores locales. Project GEF 79912. La Paz: UNDP. Retrieved from http://www.bo.undp.org/content/dam/bolivia/docs/prodocs/PRODOC79912GEFForestal.PDF

Groff Greever, J. (1987). José Ballivián y el Oriente Boliviano. La Paz: Siglo.

Grugel, J., \& Riggirozzi, P. (2012). Post-neoliberalism in Latin America: Rebuilding and Reclaiming the State after Crisis. Development and Change, 43(1), 1-21. https://doi.org/10.1111/j.1467-7660.2011.01746.x

Gudynas, E. (2010, January 30). El nuevo extractivismo progresista. Nueva Cronica, p. 7.

Gudynas, E. (2012). Estado compensador y nuevos extractivismos. Las ambivalencias del progresismo sudamericano. Nueva Sociedad, (237), 128-146.

Gudynas, E. (2015). Extractivismos. Ecología, economía y política de un modo de entender el desarrollo y la Naturaleza. CEDIB - CLAES.

Haarstad, H., \& Anderson, V. (2009). Backlash Reconsidered: Neoliberalism and Popular Mobilization in Bolivia. Latin American Politics and Society, 51(4), 1-28.

Harvey, D. (2005). A Brief History of Neoliberalism. Oxford: Oxford University Press.

Himley, M. (2008). Geographies of environmental governance: The nexus of nature and neoliberalism. Geography Compass, 2(2), 433-451.

Hirsch, C. (2017). Makers and shapers of environmental policy making: Power and participation in forest legislation in Bolivia. Journal of Rural Studies, 50, 148-158. https://doi.org/10.1016/j.jrurstud.2016.11.013

Hope, J. (2016). Losing ground? Extractive-led development versus environmentalism in the Isiboro Secure Indigenous Territory and National Park (TIPNIS), Bolivia. The Extractive Industries and Society, 3(4), 922-929. https://doi.org/10.1016/j.exis.2016.10.005

Kaup, B. Z. (2010). A Neoliberal Nationalization?: The Constraints on Natural-Gas-Led Development in Bolivia. Latin American Perspectives, 37(3), 123-138. https://doi.org/10.1177/0094582X10366534

Kaup, B. Z. (2012). Market justice: Political Economic Struggle in Bolivia. New York City: Cambridge University Press. 
Kaup, B. Z. (2014). Divergent Paths of Counter-Neoliberalization: Materiality and the Labor Process in Bolivia's Natural Resource Sectors. Environment and Planning A, 46(8), 1836-1851. https://doi.org/10.1068/a130194p

Kennemore, A., \& Weeks, G. (2011). Twenty-First Century Socialism? The Elusive Search for a Post-Neoliberal Development Model in Bolivia and Ecuador. Bulletin of Latin American Research, 30(3), 267-281. https://doi.org/10.1111/j.1470-9856.2010.00496.x

Kohl, B. (2002). Stabilizing neoliberalism in Bolivia: popular participation and privatization. Political Geography, 21(4), 449-472. https://doi.org/10.1016/S0962-6298(01)00078-6

Kohl, B. (2003). Restructuring Citizenship in Bolivia: El Plan de Todos. International Journal of Urban and Regional Research, 27(2), 337-351. https://doi.org/10.1111/1468-2427.00451

Kohl, B., \& Farthing, L. (2012). Material constraints to popular imaginaries: The extractive economy and resource nationalism in Bolivia. Political Geography, 31(4), 225-235. https://doi.org/10.1016/j.polgeo.2012.03.002

Laing, A. F. (2015). Resource Sovereignties in Bolivia: Re-Conceptualising the Relationship between Indigenous Identities and the Environment during the TIPNIS Conflict: Resource Sovereignties in Bolivia. Bulletin of Latin American Research, 34(2), 149-166. https://doi.org/10.1111/blar.12211

Larner, W. (2003). Neoliberalism? Environment and Planning D : Society and Space, 21(5), 509-512. https://doi.org/10.1068/d2105ed

Lavaud, J.-P. (2007). Bolivie : un avenir politique hypothéqué? Nueva Sociedad, 209.

Le Gouill, C. (2016). La politique minière du gouvernement d'Evo Morales : entre mythes et pragmatisme politique. IdeAs. Retrieved from http://ideas.revues.org/1695

Lerch, L. (2014). The Geopolitics of Land: Population, Security and Territory Viewed from the International Financing of the Land Survey in Bolivia (1996 - 2013). Journal of Latin American Geography, 13(1), $137-158$.

Macdonald, L., \& Ruckert, A. (2009). Post-neoliberalism in the Americas. New York - London: Palgrave Macmillan.

McCarthy, J. (2005). Scale, Sovereignty, and Strategy in Environmental Governance. Antipode, 37(4), 731-753. https://doi.org/10.1111/j.0066-4812.2005.00523.x

MDRAyMA. (2008). Política Nacional para la Gestión Integral de los Bosques. La Paz; Bolivia: Ministerio de Desarrollo Rural, Agropecuario y Medio Ambiente.

Ministerio de Planificación del Desarrollo. (2015). Contribución prevista determinada nacionalmente del Estado Plurinacional de Bolivia. La Paz. Retrieved from http://www.planificacion.gob.bo/sites/folders/1.BOLIVIA CONTRIBUCIÓN (doc).pdf

Morales, E. (2015). Discurso presidencial de Evo Morales. Yapacani, Santa Cruz. Yapacani: Ministerio de Comunicacion. Estado Plurinacional de Bolivia. Cambio. Retrieved from http://www.comunicacion.gob.bo/sites/default/files/media/discursos/Discurso\%20Presidencial\%201906-15.pdf 
Müller, R., Pacheco, P., \& Montero, J. C. (2014). The context of deforestation and forest degradation in Bolivia Drivers, agents and institutions. Bogor, Indonesia: CIFOR.

Müller, R., Pistorius, T., Rohde, S., Gerold, G., \& Pacheco, P. (2013). Policy options to reduce deforestation based on a systematic analysis of drivers and agents in lowland Bolivia. Land Use Policy, 30(1), 895907. https://doi.org/10.1016/j.landusepol.2012.06.019

Murphy, J. T., \& Lawhon, M. (2011). Market intermediaries and rural people in Bolivia's forest products sector: Are trusting partnerships possible? Singapore Journal of Tropical Geography, 32(2), 203-219. https://doi.org/10.1111/j.1467-9493.2011.00429.x

Nitler, J. (2001). Bolivia sustainable forestry management project. Chief of party end of tour report (p. 30). Washington D.C.: USAID, Chemonics International Inc.

Ong, A. (2007). Neoliberalism as a mobile technology. Transactions of the Institute of British Geographers, (32), 3-8.

Ortiz, P. (2018, August 22). Indígena que recibió nueva ley del Tipnis es elegido presidente de la Cidob. El Deber.

Pacheco, P. (2003). Municipalidades y participación local en la gestión forestal en Bolivia. In L. Ferroukhi, $L a$ gestión forestal municipal en América Latina (pp. 19-55). Bogor, Indonesia: CIFOR - IDRC.

Pacheco, P., Barry, D., Cronkleton, P., \& Larson, A. (2012). The Recognition of Forest Rights in Latin America: Progress and Shortcomings of Forest Tenure Reforms. Society \& Natural Resources, 25(6), 556-571. https://doi.org/10.1080/08941920.2011.574314

Pacheco, P., \& Benatti, J. H. (2015). Tenure Security and Land Appropriation under Changing Environmental Governance in Lowland Bolivia and Pará. Forests, (6), 464-491. https://doi.org/10.3390/f6020464

Pacheco, P., de Jong, W., \& Johnson, J. (2010a). The evolution of the timber sector in lowland Bolivia: Examining the influence of three disparate policy approaches. Forest Policy and Economics, 12(4), 271-276. https://doi.org/10.1016/j.forpol.2009.12.002

Pacheco, P., de Jong, W., \& Johnson, J. (2010b). The evolution of the timber sector in lowland Bolivia: Examining the influence of three disparate policy approaches. Forest Policy and Economics, 12(4), 271-276. https://doi.org/10.1016/j.forpol.2009.12.002

Peck, J., Theodore, N., \& Brenner, N. (2012). Neoliberalism Resurgent? Market Rule after the Great Recession. South Atlantic Quarterly, 111(2), 265-288. https://doi.org/10.1215/00382876-1548212

Peck, J., \& Tickell, A. (2002). Neoliberalizing Space. Antipode, 34(3), 380-404. https://doi.org/10.1111/14678330.00247

Pellegrini, L. (2011). Forest Management and Poverty in Bolivia, Honduras and Nicaragua: Reform Failures? The European Journal of Development Research, 23(S2), 266-283. https://doi.org/10.1057/ejdr.2010.49

Pellegrini, L., \& Dasgupta, A. (2011). Land Reform in Bolivia: The Forestry Question. Conservation and Society, 9(4), 274-285. 
Perreault, T. (2009). Assessing the Limits of Neoliberal Environmental Governance in Bolivia. In J. Burdick, P. Oxhorn, \& K. M. Roberts (Eds.), Beyond neoliberalism in Latin America? Societies and Politics at the crossroads (pp. 135-155). London: Palgrave Macmillan.

Perreault, T., \& Valdivia, G. (2010). Hydrocarbons, popular protest and national imaginaries: Ecuador and Bolivia in comparative context. Geoforum, 41(5), 689-699. https://doi.org/10.1016/j.geoforum.2010.04.004

Perrier Bruslé, L. (2007). The Front and the Line: The Paradox of South American Frontiers Applied to the Bolivian Case. Geopolitics, 12(1), 57-77.

Perrier Bruslé, L. (2012). Le conflit du Tipnis et la Bolivie d'Evo Morales face à ses contradictions : analyse d'un conflit socio-environnemental. EchoGéo. Retrieved from http://echogeo.revues.org/12972

Perrier Bruslé, L. (2015). La integración continental suramericana, inscripción espacial y marco ideológico. Apuntes desde Bolivia, el país de contactos. Journal of Latin American Geography, 14(2), 101-127. https://doi.org/10.1353/lag.2015.0025

Perrier Bruslé, L., \& Gosalvez, B. (Eds.). (2014). El Norte La Paz en la encrucijada de la integración. Juegos de actores y de escala en un margen boliviano. La Paz: Plural Editores, IRD Editions, UMSA.

Postero, N. G. (2007). Now We Are Citizens: Indigenous Politics in Postmulticultural Bolivia. Stanford: Stanford University Press.

Reed, M. G., \& Bruyneel, S. (2010). Rescaling environmental governance, rethinking the state: a threedimensional review. Progress in Human Geography, 34(5), 646-653.

Roca, J. L. (2001). Economia y sociedad en el Oriente Boliviano ( siglos XVI-XX). Santa Cruz: COTAS.

Ruckert, A., Macdonald, L., \& Proulx, K. R. (2016). Post-neoliberalism in Latin America: a conceptual review. Third World Quarterly, O(0), 1-20. https://doi.org/10.1080/01436597.2016.1259558

Siegel, K. M. (2017). From Neo-liberalism to Neo-extractivism. In Regional Environmental Cooperation in South America (pp. 33-61). Palgrave Macmillan, London. https://doi.org/10.1057/978-1-137-5587492

Ströher, H. (2013). Political Ecology of Former Forestry Concession Land in the Bolivian Amazon. A Case Study in the Tacana's Indigenous Land Tenure(TCO) (Master thesis). Bonn, Germany.

Svampa, M., \& Durand, G. (2011). Néo-« développementisme » extractiviste, gouvernements et mouvements sociaux en Amérique latine. Problèmes d'Amérique latine, $N^{\circ} 81(3), 101-127$. https://doi.org/10.3917/pal.081.0101

Urioste, M. (2014). Prologo. In G. Colque (Ed.), Expansión de la frontera agrícola. Luchas por el control y apropiación de la tierra en el oriente boliviano (pp. 1-4). La Paz: Tierra.

Veltmeyer, H. (2013). The political economy of natural resource extraction: a new model or extractive imperialism? Canadian Journal of Development Studies / Revue Canadienne d'études Du Développement, 34(1), 79-95. https://doi.org/10.1080/02255189.2013.764850

Veltmeyer, H., \& Petras, J. (2014). The New Extractivism: A Post-Neoliberal Development Model or Imperialism of the Twenty-First Century? London: Zed Books. 
Watts, M. (2009). Capitalism. In D. Gregory, R. Johnston, G. Pratt, M. Watts, \& S. Whatmore (Eds.), The dictionary of human geography (5th ed., pp. 59-64). Maden (USA); Oxford (UK) ; Victoria (Aus.): Wiley-Blackwell.

Webber, J. R. (2009). From naked barbarism to barbarism with benefits: neoliberal capitalism, natural gas policy, and the Evo Morales government in Bolivia. In L. Macdonald \& A. Ruckert (Eds.), PostNeoliberalism in the Americas (pp. 105-119). New York: Palgrave MacMillan.

Webber, J. R. (2011). From Rebellion to Reform in Bolivia: Class Struggle, Indigenous Liberation, and the Politics of Evo Morales. Haymarket Books.

Wilson, J., \& Bayón, M. (2017). The nature of post-neoliberalism: Building bio-socialism in the Ecuadorian Amazon. Geoforum, 81, 55-65. https://doi.org/10.1016/j.geoforum.2017.01.014

Yates, J. S., \& Bakker, K. (2014). Debating the 'post-neoliberal turn' in Latin America. Progress in Human Geography, 38(1), 62-90. https://doi.org/10.1177/0309132513500372

Zimmerer, K. S. (2015). Environmental governance through "Speaking Like an Indigenous State" and respatializing resources: Ethical livelihood concepts in Bolivia as versatility or verisimilitude? Geoforum, 64, 314-324. https://doi.org/10.1016/j.geoforum.2013.07.004 